\title{
Rhyacophila quadrata n. sp., a new caddisfly (Insecta, Trichoptera) from Eocene Baltic amber
}

\author{
Wilfried Wichard ${ }^{*}, 1$ and Christian Neumann ${ }^{2}$ \\ ${ }^{1}$ Institut für Biologie, Universität zu Köln, Gronewaldstraße 2, 50931 Köln, Germany. E-mail: wichard@uni-koeln.de \\ ${ }^{2}$ Museum für Naturkunde der Humboldt-Universität zu Berlin, Invalidenstraße 43, 10115 Berlin, Germany. \\ E-mail: christian.neumann@museum.hu-berlin.de
}

\begin{abstract}
Received 3 July 2007

Accepted 13 August 2007

Published 15 February 2008

\section{Key Words}

Rhyacophila quadrata n. sp., a new fossil caddisfly, is described from Eocene Baltic amber. The new species belongs to the family Rhyacophilidae whose extant larvae prefer cool running-water habitats. In Baltic amber, the genus Rhyacophila is now represented by only seven species, whereas more than 500 extant species are described from the Holarctic region. Differences in the biodiversity patterns of the rare fossil faunas and extant species are discussed.
\end{abstract}

Baltic amber

Eocene

Trichoptera

Rhyacophilidae

Rhyacophila

fossil taxon

\section{Introduction}

Insects of the order Trichoptera (caddisflies) are represented in Baltic amber by 22 families and comprise about $2 \%$ of all inclusions (Wichard \& Weitschat 1996). Among these, the genus Rhyacophila (Rhyacophilidae) is a rare taxon presented with six so far known fossil species (Rhyacophila kutscheri Mey, 1988; R. laminata Ulmer, 1912; R. liedtkei Wichard \& Caspers, 1991; R. occulta Hagen, 1856; R. palaepolonica Wichard \& Caspers, 1991; R. profusa Ulmer, 1912). Herein we present the description of a new fossil species preserved in Baltic amber. The new species presented below is represented by a male imago which is differentiated from all other fossil members of the genus by its square-shaped harpago.

Today, Rhyacophila is a very large genus of the Trichoptera which includes approximately 500 known species distributed over the northern hemisphere, reported as far south as the Atlas mountains in northern Africa and ranging southwards towards Java in Indonesia to the Oriental region, and northern Mexico in the Nearctic region (Schmid 1970; Wiggins 2004). It should be interesting to examine the occurrence patterns of Rhyacophila in Eocene amber with respect to modern biodiversity dynamics and biogeographical patterns of the genus. Today, aquatic larvae of Rhyacophila occur in almost all running-water habitats of the northern hemisphere. In the Eocene, however, species belonging to Rhyacophila are exceptional findings. We discuss how far climate change throughout the Cenozoic influenced the biodiversity and distribution of Rhyacophila.

\section{Systematic palaeontology}

Order Trichoptera Kirby, 1813

Family Rhyacophilidae Stephens, 1836

\section{Rhyacophila Pictet, 1834}

\section{Type species. Rhyacophila vulgaris Pictet, 1834}

Diagnosis. Antennae shorter than forewing, filiform; the basal segment somewhat thicker than the following segments. Maxillary palp five-segmented; second segment button-shaped, fifth segment terminating in a sharp-pointed edge. Labial palp three-segmented, terminal segment ending in a sharp-pointed edge. Ocelli present. Forewing

\footnotetext{
* Corresponding author
} 
with fork I, II, III, IV, V, discoidal cell short and open, thyridium cell closed. Hindwing without fork IV, discoidal cell open in both wings, thyridium cell closed. Tibial spurs: 3,4,4. Male genitalia: Inferior appendages (claspers) two-segmented, phallic apparatus with a ventral lobe and a pair of lateral lobes (parameres). Tenth tergite posteriorad and/or ventrad, divided into a pair of lateral lobes; anal sclerite exists below the apex of tenth tergite. Ninth segment with dorsoapical lobe.

Stratigraphic and geographic range. Late Cretaceous sediments of Siberia; Eocene strata of Central and northern Europe (Baltic and Saxonian amber); Recent: distributed all over the Holarctic regions.

\section{Rhyacophila quadrata $\mathbf{n}$. sp.}

\section{Figures 1-3}

Derivation of name. The species is named after the square-shaped harpago ( $=2$ nd segment of the inferior appendages) which is easily recognized.

Holotype. MB.I 5101. The only specimen and holotype is a male imago preserved in Baltic amber. The original label indicates that the specimen was sold to the Museum für Naturkunde by the company B. Stürtz (Mineralogisches und paläontologisches Kontor), Bonn. The holotype is stored in the palaeozoological collection of the Museum für Naturkunde.

Type locality. Glacial erratics, exact locality unknown.

Formation and age. The age of Baltic amber is Middle to Late Eocene.

Amber matrix and preservation. The imago is embedded in bright-coloured transparent amber, which exhibits tiny cracks around the embedded insect, thus slightly obscuring the view. This concerns especially the dorsal part of the head. The animal is embedded with the wings spread and the venations of the right forewing and hindwing are well visible. Small areas of the apex of both forewings are damaged but do not hinder the reconstruction of the overall venation. From the ventral side, small cracks and oak stellate hairs obscure the complete view on the animal, although the right eye and the maxillary- and labial palps which are typical characters for the genus Rhyacophila can be recognized. The legs are arranged symmetrically and cover both, thorax and abdomen but allow to recognize the genital parts. The genitals parts are best seen from the ventral side, the dorsal and lateral view is hindered by the wings. However, from an obliquelateral view, the genital parts are still visible.

To prevent decay of the amber matrix and to protect the holotype, the amber piece was embedded in two-component synthetic resin using Casring Resin.

Diagnosis. Head with filiform antennae, ocelli present, maxillary palps 5-segmented, second segments button-shaped and covered with hairs. Last segments of the maxillary and labial palps terminate with articulate tips. Forewing with fork I, II, III, IV, V, hindwing without fork IV, in both wings discoidal cell open, thyridium cell closed. Tibial spurs: $3,4,4$

Male genitalia: Inferior appendages (claspers) are two-segmented, basal segments (coxopodite) longer than wide (about $2: 1$ ); in latera view the second segment (harpago) is rectangular, its distal margin is slowly concaved. In ventral view median phallic apparatus seems to be spicular and arcuate, with lateral lobes forming conch-like plates. The genitalia possesses dorsally two sclerite needles probably of tenth tergite bend ventrodistad.

Rhyacophila quadrata $\mathrm{n}$. sp. is differentiated from all other known Eocene Rhyacophila-species by the square shaped harpago.

Description. Size: Length of forewing (measure of body length): $5 \mathrm{~mm}$, Fig. 1.

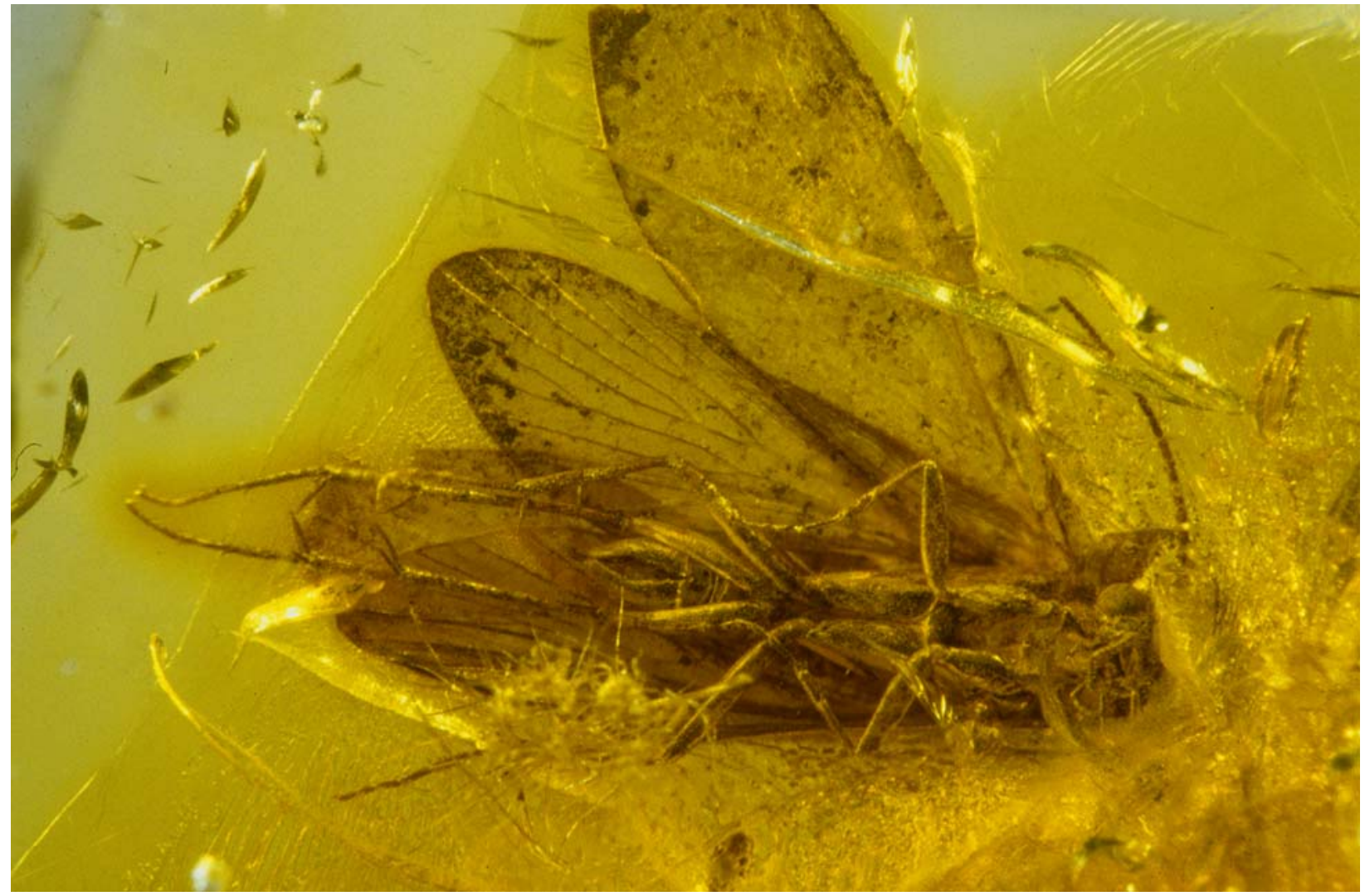

Figure 1. Ventral view of Rhyacophila quadrata n. sp., holotype MB.I 5101 from Baltic amber, length of forewing $=5 \mathrm{~mm}$. This figure is available in colour online at museum-fossilrecord.wiley-vch.de. 


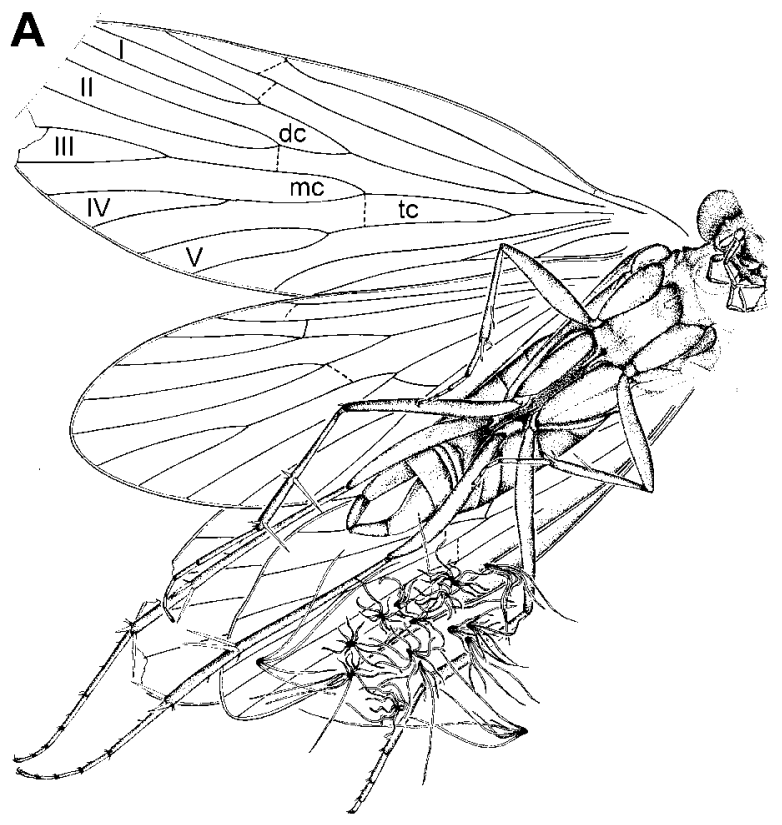

B

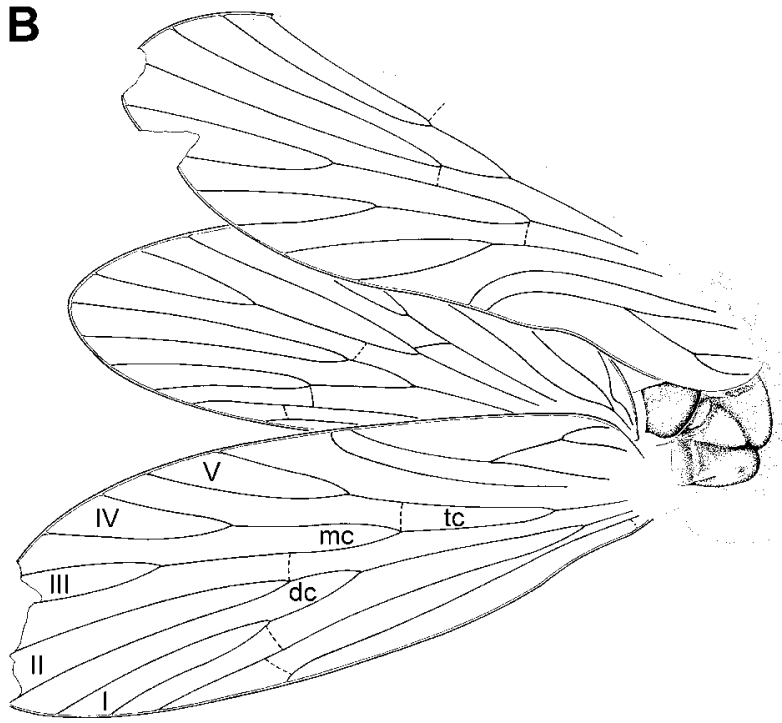

Figure 2. Rhyacophila quadrata n. sp. A. Drawing in ventral view; B. drawing in dorsal view. I, II, III, IV, V - apical forks I-V; dc - discoidal cell; me - median cell; tc - thyridium cell.

Head (Fig. 2A): characterized by the large, laterally protruding eyes and three clear ocelli: one ocell is situated between the base of the antennae, whereas the others are situated just posterior of each antenna. The antennae are filiform with the first segment enlarged. The antennae are somewhat shorter than the forewing. Warts of the head capsule are densely haired. The maxillary palps are 5-segemented, the second segment is enlarged in button-shaped manner, the terminal segment is pointed. The three-segmented labial palps terminate also in a pointed third segement.

Thorax: Pronotum with two elongate and hair-covered warts. The mesonotum is followed on both sides by the scutum, scutellum and postscutellum, also with hair-covered warts. Warts of both tegula and the wing bases possess an extensive hair-cover. Length and density of hairs declines continuously towards the wing tips.
Legs (Fig. 2A): Three pairs of slender legs, with the hind legs longer than the middle legs and the forelegs shortest. Tibia of middle- and hindlegs with two preapical spurs and two apical spurs whereas each fore leg has two apical spurs and one preapical spur; tibial spurs: $3,4,4$.

Wings (Fig. 2A, B): The forewing measures ca. $5 \mathrm{~mm}$ and the hindwing ca. $4 \mathrm{~mm}$ in length. Shape is rather similar. Both are moderately broad and smoothly rounded distally. The venation of fore and hind wings is similar. In the forewing, the discoidal cell is short and open; fork I and fork II are without crossvein; fork I is shorter than fork II. Between fork III and IV crossvein is lacking; the median cell is open. Crossvein $\mathrm{m}$-cu appears to be between media $\mathrm{M}$ and cubitus $\mathrm{Cu} 1$, meaning that the elongated thyridium cell is closed. Cubitus $\mathrm{Cu} 2$ and the anal vein $\mathrm{A} 1+2+3$ do not join, but meet the wing margin in a certain distance. Due to the diffuse preservation of both forewings it has to remain doubtful if subcosta $\mathrm{Sc}$ or radius $\mathrm{R} 1$ form a short fork distally; we suggest that this fork is missing and a crossvein is suggested between R1 und Sc. Apart from this, the forewing has probably the two further crossveins: $r$ and $r-m$. In the shorter hindwing, subcosta Sc and radius R1 are not forked distally. The terminal forks I, II, III and V show the same pattern as in the

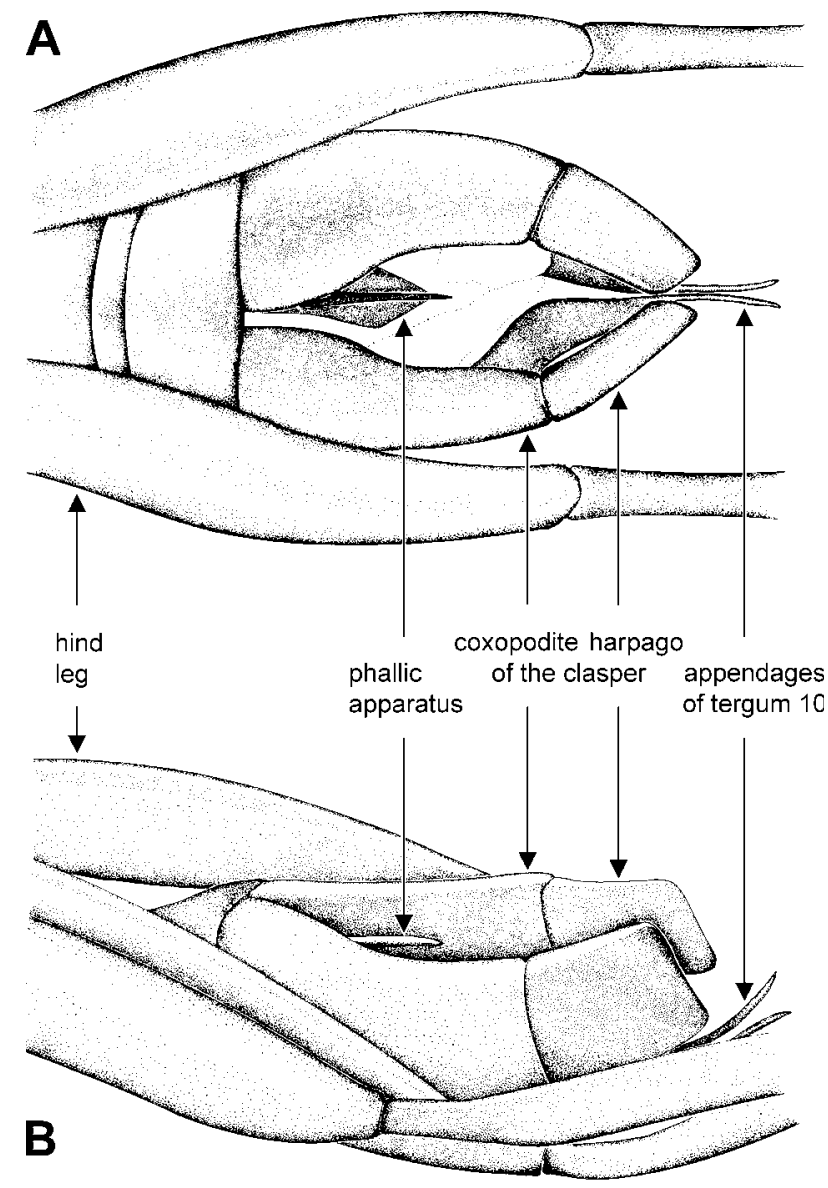

Figure 3. Rhyacophila quadrata n. sp. A. Male genitalia in ventral view; B. Male genitalia in lateral view. 
forewing; however, there is no fork IV. The discoidal cell and the median cell are open. Only one well developed crossvein $r$ is found between $R 1$ and $R 2+3$. The crossvein $r-m$ between $R$ and $M$ appears to exist. $A$ further crossvein between $\mathrm{M}$ and $\mathrm{Cul}$ closes the thyridium cell.

Male genitalia (Figs 3A, B): In ventral view the inferior appendages (claspers) are two-segmented, basal segments (coxopodite) longer than wide (about $2: 1$ ); in lateral view the second segment (harpago) is rectangular, its distal margin is slowly concaved. In ventral view, the median phallic apparatus is spicular and arcuate, with lateral lobes forming conch-like plates. Further details of phallic apparatus are not visible. Dorsally, the genitalia exhibit two ventrodistad bent sclerite needles, probably descendents of the tenth tergite.

\section{Discussion}

Trichoptera are holometabolous insects with aquatic larval stages which are found in almost all freshwater communities. The aquatic larvae of Rhyacophila are free-living predators and adapted to cool running-water habitats from small mountain creeks to large lowland rivers. Rhyacophila larvae are among the most common and most typical aquatic insects of Holarctic runningwater habitats. Most of their univoltine life span is spent in the water unless the fifth larval state is finished. Following a short pupal phase protected beneath a dome-shaped chamber made of coarse sand grains, the hatched imagines change from the aquatic to the terrestrial environment. The remaining few weeks of their life are spent with mating and reproduction. Flying activity depends strongly from daytime and weather conditions. Flights are frequently interrupted by short roosting intervals when the insects rest on leaves of nearby shrubs and trees. There is no reason to assume that the life cycle of Rhyacophila differed much from today during Eocene times 40-50 Mio years ago. Therefore, we suggest that also the caddisflies of the amber forest used trees as roosting places. Some of these trees probably belonged to resin-producing species such as the amber pine (Pinus succinifera). Occasionally, unfortunate individuals were trapped by a covering resin flow. Thus, some specimens of Rhyacophila have been entombed and finally fossilized in Baltic amber.

In the Baltic amber, species belonging to the Rhyacophilidae are extremely rare. Among the several thousand trichopterans which have been determined to genus level by one of us (WW) during the last three decades, less than twenty specimens were identified as belonging to the genus Rhyacophila. Already Hagen recognized the family Rhyacophilidae to be extremely rare in Baltic amber and described only one taxon (R. occulta Hagen, 1856 in Pictet-Baraban \& Hagen 1856). The rarity of rhyacophilds is also confirmed by observations made by Ulmer (1912) who listed not more than three specimens belonging to two species (R. profuse, Ulmer 1912; R. laminata Ulmer, 1912). Today, the larvae prefer cool running-water habitats in temperate climate. The rare occurrence of Rhyacophila imagines (less than $0.1 \%$ of the trichopterans) in Baltic amber provides clues for the evolution of the genus depending on climatic conditions: Cooling at the end of the Eocene led to the vanishing of the amber forest ecosystem. This climatic change altered flora and fauna of the northern hemisphere dramatically and led to extinction and/or radiation of many groups reported from Baltic amber. Only seven species of Rhyacophila are known from the tropical to subtropical Eocene Baltic amber. In contrast, more than 500 extant species of genus Rhyacophila have been described from cool running-water habitats in the temperate realm (Wiggins 2004) suggesting a post-Eocene radiation. The appearance of the first Rhyacophilidae is postulated for the Jurassic (Ivanov \& Sukatsheva 2002). The fossil evidence for this early phase of diversification is not yet significant; Sukatsheva (1985) described a fragmentary forewing impression as "?Rhyacophila sp." which may refer to a rhyacophilid. However, the oldest doubtless fossil Rhyacophilidae known for the time being, is Rhyacophila antiquissima Botosaneanu \& Wichard, 1983, from the Late Cretaceous amber from Siberia (Taymyr).

\section{Acknowledgements}

We wish to thank Agnes Gras for preparing the amber piece. The drawings have been produced by Claus Lüer who is gratefully acknowledged. We are most grateful to Andrew and Emma Ross, London, and Rüdiger Wagner, Schlitz, for useful comments on the manuscript.

\section{References}

Botosaneanu, L. \& Wichard, W. 1983. Upper-Cretaceous Siberian and Canadian Amber Caddisflies (Insecta: Trichoptera). - Bijdragen tot de Dierkunde 53: 187-217.

Ivanov, V. D. \& Sukatsheva, I. D. 2002. Order Trichoptera Kirby, 1813 - The Caddisflies. - In Rasnitsyn, P. \& Quicke, D. L. J (eds). History of Insects 2. Kluwer Academic Publishers, Dordrecht: pp. 190-220.

Kirby, W. 1813. Strepsiptera, a new order of insects proposed; and the characters of the order, with those of the genera, laid down. Transactions of the Linnaean Society of London 11: 86-123.

Mey, W. 1988. The caddisflies of the Saxonian Amber (III) (Trichoptera). - Deutsche Entomologische Zeitschrift 35: 299-309.

Pictet, F. J. 1834. Recherches pour server a l'histoire et a l'anatomie des phryganides. Geneva.

Pictet-Baraban, F. J. \& Hagen, H. 1856. Die im Bernstein befindlichen Neuropteren der Vorwelt. - In Berendt, G. C. (ed.). Die im Bernstein befindlichen organischen Reste der Vorwelt, 2, II. Abt. Nicolai, Berlin. pp. 41-125.

Schmid, F. 1970. Le genre Rhyacophila et la famille des Rhyacophilidae (Trichoptera). - Memoires de la Societe Entomologique du Canada 66: 1-230.

Stephens, H. 1836. Illustrations of British Entomology, Vol. 6. Baldwin \& Cradock, London. 
Sukatsheva, I. D. 1985. Yurskie rucheiniki yuzhnoi Sibiri. [Jurassic caddisflies of Southern Siberia]. In Rasnitsyn, A. P. (ed.). Yurskie nasekomye Sibiri i Mongolii. (Jurassic insects of Siberia and Mongolia). - Trudy Paleontologicheskogo Instituta 211: 115-119.

Ulmer, G. 1912. Die Trichopteren des Baltischen Bernsteins. - Beiträge zur Naturkunde Preussens 10: 1-380.
Wichard, W. \& Caspers, N. 1991. Caddisflies of Baltic amber. 2. Fossil Species of the genus Rhyacophila. - Proceedings of the $6^{\text {th }}$ International Symposium on Trichoptera, Lodz 1989: 447-451.

Wichard, W. \& Weitschat, W. 1996. Wasserinsekten im Bernstein. Eine paläobiologische Studie. - Entomologische Mitteilungen aus dem Löbbecke Museum + Aquazoo, Beiheft 4: 1-122.

Wiggins, G. 2004. Caddisflies - The Underwater Architects. University of Toronto Press, Toronto. 